\title{
THE EXPRESSION OF OPTATIVE MODALITY OF UNDESIRABILITY WITH THE INFINITIVE CONSTRUCTIONS
}

\author{
Ekaterina A. Khuzina ${ }^{1}$ \\ Dinara D. Khairullina ${ }^{2}$
}

\begin{abstract}
Linguistic modality as one of the key categories that connect sentences (statements) with extralinguistic reality and realize its communicative potential, is characterized by active interest of researchers and according to $\mathrm{G}$. V. Bondarko "is steadily maintained as a recognized subject of debate". The interest in this category has increased notably in recent decades, when the functional approach firmly established in linguistics and the consistent attention to the human factor as an important extralinguistic component of language change is clearly evident. The study of the categories of modality are the subject of many linguistic works the best known are the works of V. V. Vinogradov, Sh. Bally, V. G. Admoni, G. A. Zolotova, G. V. Olshanskii, G. V. Bondarko, N. Yu.Shvedov, N. E. Belyaeva, S. S. Vaulina, G. A. German, N. E. Petrova, L. S. Ermolaeva, V. Z. Panfilov, N. K.
\end{abstract} Dmitrieva, Coates[1-4], Halliday [5], Hockett [6] etc. V. V. Vinogradov is considered to be the founder of the theory of modality, his contribution in this issue, it is still very important for linguists. After V. V. Vinogradov, we understand modality as the ratio of the content of the narrative to reality (reported to its real implementation) from the point of view of the speaker. Our appeal to semantically capacious and used in various speech situations and with different purposes Russian proverbs is reasonable. The studied units, being stable and reproducible in speech by synthesis polyfunctional sayings, represent the secondary linguistic signs (closed steady phrase), are markers of the situations or relations between the realities, and also have an integralsemantic, expressive-shaped structures. This article describes the construction with the infinitive in the role of

\footnotetext{
${ }^{1}$ Kazan Federal University, Naberezhnye Chelny Institute, e-mail: eka5551@ rambler.ru tel. 89631239610.

${ }^{2}$ Kazan Federal University, Naberezhnye Chelny Institute.
} 
predicative centre on the example of Russian proverbs and sayings, the issue is due to insufficient knowledge of proverbs and sayings as means of verbal representation of the expression with a hint of undesirability.

Keywords: modality, expression, desire, infinitive constructions, Proverbs, sayings.

\section{Introduction}

The problem of modality is not new to linguistics and has a fairly long history of study. However, despite the large number of works, the issue of modality has not received a universally acceptable solution in modern science. The diversity and ambiguity of this category allows to approach issues of modality from different perspectives and conduct research in different directions. The question of the boundaries of the category of modality is solved by different researchers in different ways. Modality is a universal category and mandatory language constituting symptom of any statement. Every utterance has a propositional content, which is based on the act of predication, i.e., mappings of the object of thought and its basis through the approval or denial of the relationship between them that is expressed by the category of predicativity in the language. Modality is one of the ways of actualization of a proposition, along with other categories such as time, person, view etc. Today in the native linguistics the functionalsemantic approach to the study of linguistic phenomena is of considerable interest. Among the variety of linguistic theories in the study of syntax of the Russian language the particularly significant place is taken by the theory of optatives developed by Professor E. V. Altybaeva. The Central and defining concepts in the theory of optatives are desirability and optatives, correlated as "the signified" and "signifier" [7].

The desirability as "signified" expresses the attitude to reality as a desirable phenomenon, event (preferred modality), optative, in this regard, we consider the expression of will in the model of a combination of a modal verb with the meaning of will and the infinitive, and will also concentrate on the constructions with the infinitive in the role of predicative centre. It must be noted that the expression of the modal relation to the action of the infinitive is 
the basic content of a variety of constructions formed with the participation of the infinitive. We won't comment on the types of the mood of the Russian verb, their ratio, as it is beyond the scope of our study.

The will is understood by us in a broad sense. This includes various shades of modal meaning of will: intention, willingness and attempts to perform an action, desire, reluctance, agreement, and disagreement. They combine the "strong-willed relation of the subject to action, conscious entity no matter what circumstances led to it, as its own volitional motive" [8].

\section{Materials and methods}

Our appeal to semantically capacious and used in various speech situations and with different purposes Russian proverbs is for a reason. The studied units, being stable and reproducible in speech synthesis polyfunctional sayings, represent the secondary linguistic signs (closed steady phrase), are markers of the situations or relations between the realities, and also have an integral-semantic, expressiveshaped structures.
224

The relevance of this article due to the unflagging interest in the study of proverbs and sayings, which combines the characteristics of units of different language levels; the active use of proverbs with infinitive component; and insufficient knowledge of proverbs and sayings as means of representation of verbal expression.

Material of the study consists of 100 stable units (Proverbs and sayings), extracted from the "Dictionary of proverbs of the Russian nation" by V. I. Dal [9].

In this article we will focus on constructions with the infinitive in the role of predicative centre. Our focus, therefore, will be some types of mononuclear sentenses: definitelypersonal, generalized personal, impersonal and infinitive sentences with infinitive as predicate. It must be noted that the expression of the modal relation to the action of the infinitive is the basic content of a variety of constructions formed with the participation of the infinitive. The results of studies on the material of proverbs and sayings containing the infinitive, suggest that, in addition to cases where the modal plan of the utterance is determined by other parts 
of the sentence, and the infinitive bears only the reflected modal value, there are cases where the infinitive discovers the ability to express its modal value. For the analysis of infinitive constructions we use various scientific methods: conceptual analysis methods, modeling, generalization and comparison, analysis of the lexicographic definitions, the method of free associative experiment, the elements of quantitative analysis, etc.

\section{Results and Discussion}

One of the essential forms of expression of predicativity is a particular modality of the predicate. The infinitive, becoming a predicate, necessarily acquires a certain modal coloring. The modality of the infinitive verb is not dependent on the lexical meaning of other words. Both from modern and genetic points of view, the obligation or necessity, which through analysis can be revealed, in varying degrees, in all places of the infinitive sentences, which does not exclude the presence and number of other modal shades that make up the characteristics of certain groups of these proposals, should be recognized as a distinctive modal value of the independent predicative infinitive [10]. The modality of the dependent infinitive is determined lexically; the modality of the independent predicative infinitive is grammatical, as it is peculiar to a particular syntactic form of the infinitive - independent predicative infinitive [11]. It is known that the infinitive form of the Russian language has a common functional feature: it denotes an action referring to which intentional setting of a subject or assessment (the subject of the assessment may coincide with the subject of the action or they may be external) is evident, and thus objectifies the action in relation to its subject or to the subject of the evaluation: Горе наме - гречневая каша, есть не хочется, а покинуть жаль. (Our sorrow is like buckwheat porridge, is not desirable to eat it, and we are sorry to leave it.) In the presented example, the subject of assessment coincides with the subject of the action expressed by the presented modality of expression with a hint of undesirability to perform an action "is not desirable".

The will is understood by us in a broad sense. This includes various shades of modal meaning of will: intention, willingness and attempts to 
perform an action, desire, consent. They combine the "strong-willed relation of the subject to action, of which the subject is conscious - no matter what circumstances led to it - as his own volitional impulse" [12].

It is interesting to note the point of view of A. V. Bondarko, who tells about the concept of voluntariness. The modal value of voluntariness, in his opinion, is to express the volitional orientation of the subject to take action. This value is represented mainly by combinations of the infinitive with words expressing desire, intention, inclination, desire, intention ((xomemb, надеяться, стремиться, стараться, собираться, готовится, мечтать, любить, нравиться - to wish, to hope, to strive, to try, to gather, prepares, to dream, to love, to like, etc.) [8].

\section{Conclusions}

The modal value of the expression with a hint of undesirability can be expressed either by attaching the negative particles "not": хотел -не хотел, желал-не желал (want - not to want, desire - not to desire); or it may be inherent in the lexical meaning of a
226

modal verb: избегать, расхотеться (avoid, stop wishing). The semantic structure of modal components is merged by the dominant meaning of "undesirable actions". So, in the language of proverbs and sayings the most productive is the verb "want" with the joining of the negative particle not: Учить дураков - не жалеть кулаков. Горе наме - гречневая каша, есть не хочется, а покинуть жаль. На что за тем гоняться, кто не хочет знаться? Жениться, так не лениться; хоть не хочется, да вставай! Хороших не отдают, а плохую взять не хочется. Даром не берут, придачи дать не хочется. Такое житье, что житье не хочется. Богатому и умирать не хочется. (To teach fools we need to use our fists a lot. Our sorrow is like buckwheat porridge, is not desirable to eat it, but we are sorry to leave it. What is the purpose of chasing a person, who does not want to know us? If you want to get married, don't be lazy; even if you do not want to, get up! Good people are not given, and it is not desirable to take a bad one. The gift is not taken, I do not want to give more for it to be taken. Such life is not desirable. Rich people do not want to die). 
There are frequent cases of expression of the modality with a hint of undesirability and desirability of the action in one proverb: Не хочу учиться, хочу жениться. Всяк хочет взять, а никто не хочет дать. (I don't want to learn, I want to get married. Everyone wants to take and nobody wants to give). These examples do not represent real actions, and only reports on the desirability, undesirability of any action. We are talking about the will of the subject, its unwillingness to perform the action named by the infinitive "to learn, to marry," "to take, to give." The action is presented as a potential, as it is unknown whether it will be implemented.

It should again be noted that the infinitive constructions are widely represented in the proverbs of the Russian people. As research material, selected proverbs are informative, rich in variety of verbal lexemes. Aesthetic value of paremiological units is manifested differently, as it is a phenomenon of high skill, with the embodiment of aesthetic principles that are highly valued in art.

\section{Conclusion}

227

Thus, in the performed analysis we came to the conclusion that the expression of will, is, no doubt, a broader concept, which includes desire, intention, command, recommendation, advice, reflection. The modal value of the expression with a hint of undesirability of the action is implemented in the popular sayings in the composition of the predicate with a modal verb "to want" with the joining of the negative particle not. So, "want" takes on the connotation of undesirability of an action and is the most frequent in use and neutral by stylistic coloring, widely represented in proverbs and sayings. Summing up, it should be noted that the value of the expression with a hint of undesirability is inherent in the semantics of the auxiliary verb, or another component, which is combined with the infinitive. The meaning of the lack of hope for the implementation of the action lies in the semantics of personal and predicative verbs, nouns combined with the infinitive, and the value of involuntariness of the reluctance is expressed by impersonal verbs and predicative, nouns in combination with the infinitive. 


\section{ACKNOWLEDGEMENTS}

The work is performed according to the Russian Government Program of Competitive Growth of Kazan Federal University.

\section{References}

Coates, J. The semantics of the mood auxiliaries. - London: Croom Helm, 1983. $-259 \mathrm{p}$.

Coates J. Epistemic modality and spoken discourse // Transactions of the Philological Society - 1987 - pp.110131.

Coates J. Modal meaning: the semanticpragmatic interface // Journal of Semantics. - I990. - Vol. 7 - No 1. - p. 53-63.

Coates, J. The semantics of the mood auxiliaries. - London: Croom Helm, 1983. $-259 \mathrm{p}$.

Halliday M. A. K. An introduction to functional grammar. 2nd ed. - London: Edward Arnold, 2015. - 387 p.
Hockett, C. A Course in Modern Linguistics. - New York: Macmillan, 2016. $-621 \mathrm{p}$.

Altabaeva E. V. Optative sentences in the modern Russian language: textbook. Manual // E. V. Altabaeva. - Michurinsk, 2003. - 164 p.

Bondarko A.V. The theory of functional grammar. Introduction. Aspects.Temporal localization. Taksis // A. V. Bondarko. ; Resp. edited by A. V. Bondarko Leningrad: Nauka, 1988. $348 \mathrm{p}$

Dahl V. I. Proverbs of the Russian people // V. I. Dahl. - Moscow: Russian book, 1993. $-614 \mathrm{p}$.

Vinogradov V. V. About the category of modality and modal words in Russian language $\mathrm{V}$. V. Vinogradov. Proceedings of Institute of Russian language. - Volume 2. Izd-vo an SSSR. M. - L., 1950. - S. $38-79$.

Pavlov, V. M. Controversies of the semantic structure of impersonal sentences // V. M. Pavlov. - SPb, 1998. $-375 \mathrm{c}$. 
Periódico do Núcleo de Estudos e Pesquisas sobre Gênero e Direito Centro de Ciências Jurídicas - Universidade Federal da Paraíba V. 8 - No 05 - Ano 2019 ISSN | 2179-7137 | http://periodicos.ufpb.br/ojs2/index.php/ged/index

Timofeev K. A. On the main types of infinitive sentences of the modern Russian literary language // K. A. Timofeev. - Questions of syntax of modern Russian language. - M.: Education, 1950. $-410 \mathrm{p}$ 